\title{
Broad Diversity of Ralstonia solanacearum Strains in Cameroon
}

Gabriel Mahbou Somo Toukam, Institut de Recherche Agronomique pour le développement, IRAD, Programme Légumineuses et Cultures Maraîchères, Yaoundé, BP 2067 Yaoundé, Cameroun; Gilles Cellier and Emmanuel Wicker, CIRAD, UMRC53, Peuplement Végétaux et Bioagresseurs en Milieu Tropical (PVBMT), F-97410, SaintPierre, La Réunion, France; Caroline Guilbaud, Institut National de la Recherche Agronomique (INRA), Avignon, Station de Pathologie Végétale, BP94, Montfavet, F-84140, France; Rémi Kahane, CIRAD, UPR Horticulture, Bd de la Lironde, F-34398 Montpellier, France; Caitilyn Allen, Department of Plant Pathology, University of Wisconsin-Madison, Madison, WI 53706, USA; and Philippe Prior, CIRAD-INRA, UMRC53 PVBMT, F-97410, SaintPierre, La Réunion, France

\begin{abstract}
Mahbou Somo Toukam, G., Cellier, G., Wicker, E., Guilbaud, C., Kahane, R., Allen, C., and Prior, P. 2009. Broad diversity of Ralstonia solanacearum strains in Cameroon. Plant Dis. 93:1123-1130.

In 2005, an extensive survey of bacterial wilt in Cameroon collected 110 strains of Ralstonia solanacearum from wilting tomato, potato, pepper, huckleberry (Solanum scabrum), sesame, and amaranth. The genetic diversity and phylogeny of selected strains from Cameroon were assessed by multiplex-polymerase chain reaction (PCR), race 3/biovar 2-specific PCR, and sequence analyses of the $m u t S$ and $e g l$ genes. These data were compared with those from 33 reference strains covering the known diversity within the $R$. solanacearum species complex. Strains isolated in Cameroon clustered into three of the four known phylotypes: I (Asian), II (American), and III (African). Lowland tomato strains belonged to phylotype I and were quite homogeneous. The strains belonging to phylotype II were genetically diverse, and partitioned into subclusters IIA and IIB (sequevar 1, race 3/biovar 2). Cameroon strains in the African phylotype III were distinct from reference strains from Zimbabwe or the Indian Ocean, highlighting the genetic diversity present within this phylotype. Strains from potatoes growing in the highlands of West Cameroon fell into both phylotypes II (race 3/biovar 2) and III. These phylotype II and III highland strains attacked both potato and tomato and could therefore pose an economic threat to potato and tomato crops throughout Central Africa. This is the first comprehensive report on the genetic diversity of $R$. solanacearum strains in Cameroon.
\end{abstract}

Bacterial wilt, the vascular disease caused by the soilborne bacterium Ralstonia solanacearum, is regarded as a major limiting factor for many crops worldwide, including subsistence food crops, small farming cash crops, and industrial crops including vegetables (Solanum tuberosum, S. lycopersicum, Capsicum spp.), banana (Musa spp.), peanuts (Arachis hypogaea), and tobacco (Nicotiana tabacum) (15). Global economic losses due to bacterial wilt of potatoes have been estimated at US\$950 million per year (5). This disease,

Corresponding author: Philippe Prior

E-mail: philippe.prior@cirad.fr

Accession numbers: GenBank EF439725 to EF439812.

* The $\boldsymbol{e}$-Xtra logo stands for "electronic extra" and indicates that two supplemental tables are available online.

Accepted for publication 23 June 2009.

doi:10.1094/PDIS-93-11-1123

This article is in the public domain and not copyrightable. It may be freely reprinted with customary crediting of the source. The American Phytopathological Society, 2009. also known as potato brown rot, is caused by the biovar 2 Andean subgroup of $R$. solanacearum, historically known as race 3 biovar 2 (R3bv2). R3bv2 is a quarantine pest in Europe and North America, and is listed in the United States as a bioterrorism Select Agent (20). In Africa, losses due to this pathogen have a major socio-economic impact on key resource crops such as tomato, pepper, eggplant, and potato (43), which are a source of cash for thousands of low-income farmers, especially in Cameroon (11). Bacterial wilt severely affects huckleberry (Solanum scabrum), also called African nightshade, an indigenous leafy vegetable widely grown in the humid forest zone of West and Central Africa as a subsistence food crop and cultivated for its edible leaves in more than 20 African countries (11).

Many different strategies have been evaluated for the control of bacterial wilt. These include soil disinfection (15), soil amendment $(21,22,34)$, biological control (30,36), chemical elicitors of systemic acquired resistance (26), and the use of genetic resources such as resistant rootstock for grafting of susceptible varieties (12). To date, breeding for resistance to bacterial wilt is still considered the most promising strategy for long-lasting control (29). Unfortunately, wilt resistance often breaks down due to the genomic plasticity and the large genetic and phenotypic diversity within the $R$. solanacearum species complex $(6,10)$. For example, tomato lines that were resistant to bacterial wilt in one geographic area were susceptible in another because of local pathogen strain variation (40). In addition, the effectiveness of genetic resistance is highly dependent on the subtle interactions among host, pathogen, and environmental conditions $(14,29,40,41)$. Thus, knowledge of local pathogen diversity is a key prerequisite for successful disease resistance breeding.

Historically, R. solanacearum was subclassified into races and biovars, but these systems were neither predictive nor phylogenetically meaningful. Recently, Fegan and Prior (6) proposed a new hierarchical classification scheme, based on sequence analysis of the internal transcribed spacer (ITS) region, the endoglucanase $(e g l)$ gene, and the $h r p B$ gene, that subdivides $R$. solanacearum into phylotypes, defined as "a monophyletic cluster of strains revealed by phylogenetic analysis of sequence data" $(6,7)$. Four phylotypes were distinguished. Phylotype I corresponds to the "Asiaticum" division 1 of Cook et al. (3) and contains strains belonging to biovars 3,4 , and 5. Phylotype II corresponds to the "Americanum" division 2 of Cook et al. (3) and contains strains belonging to biovar $1 /$ race 1 , biovar 1/race 2 (Moko disease-causing strains), R3bv2, and biovar 2T strains. Phylotype III contains strains from Africa and the Indian Ocean, which belong to biovars 1 and 2T. Phylotype IV contains strains from Indonesia, some strains from Japan, and a single strain from Australia, belonging variously to biovars 1 , 2 , and 2T. Phylotype IV also contains the closely related species Ralstonia syzygii and the banana blood disease bacterium (BDB). Each phylotype can be further subdivided into sequevars based on differences in sequence of a 750-bp region of the endoglucanase $(e g l)$ gene. The phylotyping scheme proposed by Fegan and Prior (6) is broadly consistent with the former phenotypic and molecular typing 
schemes, and adds valuable information about the geographical origin and in some cases the pathogenicity of strains. A recent study (13) hybridized genomic DNA of 18 strains, representative of the known diversity within the $R$. solanacearum species complex, to a microarray of genes from the sequenced genome of strain GMI1000. The resulting hierarchical clustering of strains perfectly matched the previous classification in four phylotypes.

To date, although bacterial wilt disease is known to be widespread in Africa, the genetic diversity of $R$. solanacearum strains prevalent on the continent, and in Cameroon in particular, is scarcely documented. Strains were reported and described from potato crops in Kenya, Burundi, Nigeria, Egypt (35), South Africa (37), and Ethiopia (18), from tobacco crops in Zimbabwe (31), from eucalyptus in South Africa $(4,9)$, from groundnut in Uganda (1), and from tomato in Benin (42). However, "there is little or no published information on distribution or importance" (5).

Understanding local pathogen diversity is the foundation of a successful breeding and integrated management program (33). In Cameroon, a breeding program was launched to improve bacterial wilt resistance in pepper. The purpose of this present study was to assess the overall genetic diversity of $R$. solanacearum that may challenge new pepper germplasm. The resulting distribution and diversity map of the pathogen populations will be used to optimize this pepper breeding program, but also to focus African bacterial wilt control strategies in Solanaceous crops, including potatoes.

\section{MATERIALS AND METHODS}

Bacterial strains. Strains used in this study $(n=143)$ are listed in Table 1 and Supplemental Table 1. They include $R$. solanacearum strains from Cameroon $(n=$ $110)$ and international reference strains ( $n$ =33) provided by authors and obtained from collections (Collection Françaises de Bactéries Phytopathogènes [CFBP], Angers, France).

Strains were collected throughout Cameroon in March 2005 during an extensive survey covering a linear distance of about $2,500 \mathrm{~km}$. Fifty-two sites were identified by local or regional extension agents and surveyed for sampling. Various host species of economic importance were sampled, including tomato (Solanum lycopersicum), sweet pepper (Capsicum annuum), hot pepper (Capsicum chinense), potato (Solanum tuberosum), huckleberry ( $S$. scabrum), amaranth (Amaranthus spp.), and sesame (Sesamum spp.). Two priorities guided the survey: (i) representing the five different agro-ecological zones (AEZ) present in Cameroon (Table 2), and (ii) sampling the major vegetable cropping areas within each AEZ where bacterial wilt was known to be the major biotic constraint to crop production. Most fields had a single collection site, but some large fields were sampled at two sites. At each collection site, two or three plants showing typical bacterial wilt symptoms were cut at midstem, and stem pieces (6 to $10 \mathrm{~cm}$ long) were kept at about $20^{\circ} \mathrm{C}$ in a cool box prior to isolation of $R$. solanacearum. Sampling and isolations were done on the same day. Samples were surfacedisinfected with $70 \%$ ethanol, peeled, subsampled, and macerated in sterile distilled water. Macerates were streaked on Kel- man's triphenyltetrazolium chloride (TZC) agar medium (17) supplemented with $1 \%$ yeast extract. Plates were incubated at room temperature $\left(28 \pm 5^{\circ} \mathrm{C}\right)$. Bacterial colonies developing the typical irregular mucoid $R$. solanacearum morphotype were then subcultured on fresh TZC medium for further purification. Isolated strains of $R$. solanacearum were given an isolate number and stored in sterile water at room temperature.

A set of 44 representative $R$. solanacearum strains from Cameroon, chosen on the basis of their phylotype assignment, host

Table 1. Ralstonia solanacearum strains used in this study

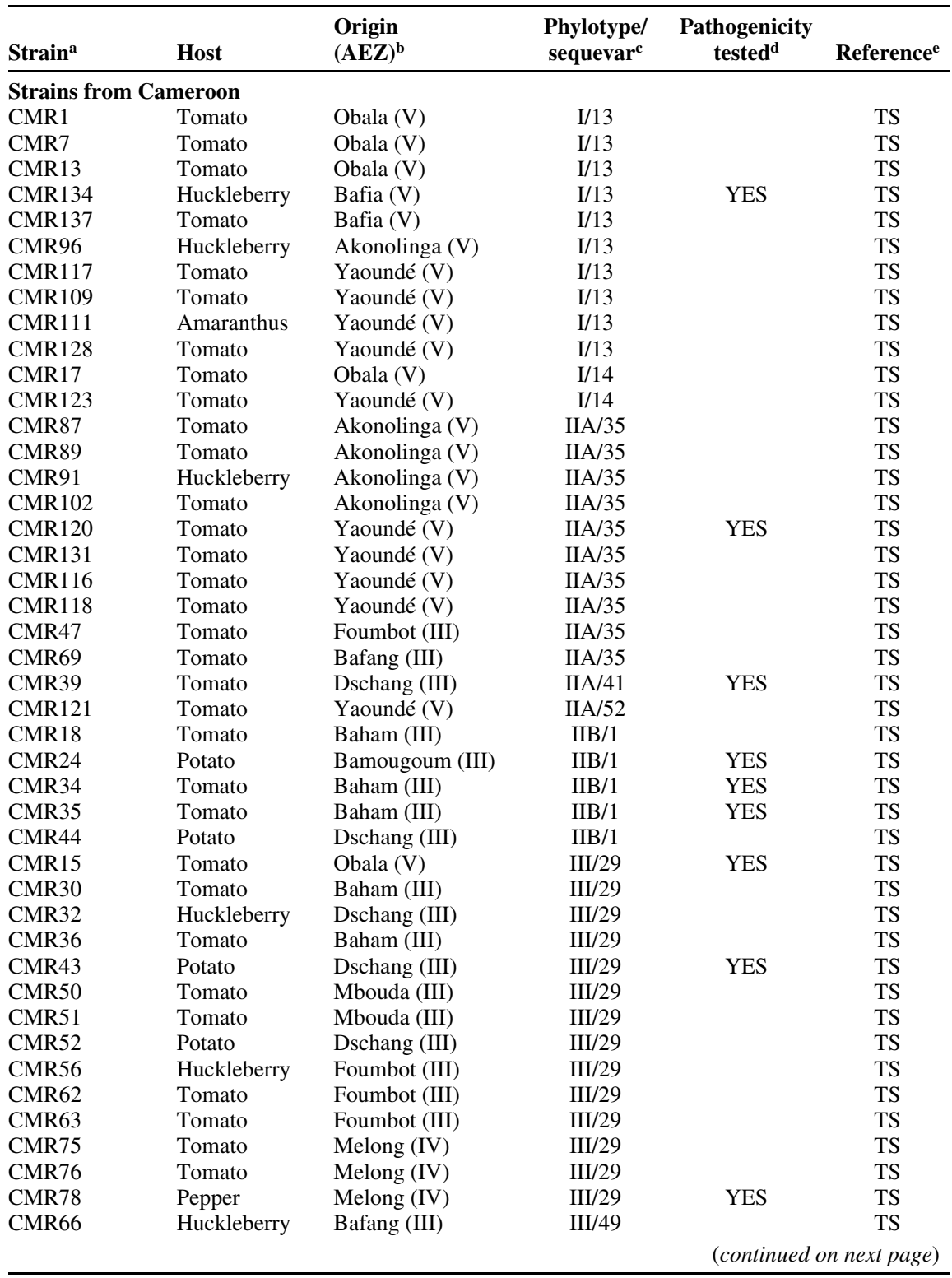

${ }^{a}$ Names of strains in Reunion collection (strains from Cameroon) and in international collections (references). CFBP: Collection Française de Bactéries Phytopathogènes [CFBP], Angers, France; RUN: collection at CIRAD-INRA Reunion.

b AEZ = agro-ecological zone (Cameroon).

${ }^{\mathrm{c}}$ Phylotypes were determined by phylotype multiplex-polymerase chain reaction (Pmx-PCR). II/1 strains amplified the race3/biovar2 (R3bv2)-specific band with primer pair 630/631. The phylotype was confirmed by phylogenetic trees based on $m u t S$, and sequevars were determined by phylogenetic trees based on egl sequence analyses as described in Fegan and Prior $(6,7)$ and Prior and Fegan $(28)$.

${ }^{\mathrm{d}}$ Pathogenicity tested on potato, tomato, and pepper (see results in Table 4).

e TS = this study; 1 = P. Prior, INRA-CIRAD, Reunion Island, unpublished data. 
of isolation, and geographical origin, were deposited at the Collection Française de Bactéries Phytopathogènes [CFBP] in Angers, France (Supplemental Table 2).

Pathogenicity tests. A set of seven $R$. solanacearum Cameroon strains and seven reference strains that spanned the genetic diversity reported in this study was tested for pathogenicity on susceptible cultivars of potato (cv. Désirée), tomato (cv. L390), and Pepper (cv. Yolo Wonder) in a growth chamber at $28 \pm 1{ }^{\circ} \mathrm{C}$ day $/ 24 \pm 1{ }^{\circ} \mathrm{C}$ night, relative humidity of $90 \pm 5 \%$ and a $14 \mathrm{~h} / 10$ $\mathrm{h}$ photoperiod. Bacterial suspensions were prepared in Tris buffer $(0.01 \mathrm{M}$ Tris $/ \mathrm{HCl}$, $\mathrm{pH}$ 7.2) and spectrophotometrically ad- justed to $\mathrm{OD}_{600 \mathrm{~nm}}=0.1$ (approximately $10^{8}$ $\mathrm{CFU} \mathrm{ml} \mathrm{m}^{-1}$ ). The root system of each plant was wounded with a scalpel; then $5 \mathrm{ml}$ of inoculum per plant was poured on the wounded root system of 10 plants belonging to each of the three susceptible plant species at the three to four fully expanded leaf stage. Ten plants of each species, drenched with $0.01 \mathrm{M}$ Tris buffer $(\mathrm{pH}$ 7.2), were used as controls. Symptom development in inoculated plants was monitored every 4 to 5 days for 4 weeks after inoculation. If at least one plant showed typical wilt symptoms, the interaction was classified as compatible (pathogenic).

Table 1. (continued from preceding page)

\begin{tabular}{|c|c|c|c|c|c|}
\hline Strain $^{a}$ & Host & $\begin{array}{l}\text { Origin } \\
(\mathbf{A E Z})^{\mathrm{b}}\end{array}$ & $\begin{array}{l}\text { Phylotype/ } \\
\text { sequevar }^{\mathrm{c}}\end{array}$ & $\begin{array}{c}\text { Pathogenicity } \\
\text { tested }^{\mathbf{d}}\end{array}$ & Reference \\
\hline \multicolumn{6}{|c|}{ Reference strains } \\
\hline R292 & Mulberry & China & $\mathrm{I} / 12$ & & (27) \\
\hline JT523 & Potato & Reunion Is. & $\mathrm{I} / 13$ & & (27) \\
\hline CFBP765 & Tobacco & Japan & $\mathrm{I} / 15$ & & (27) \\
\hline ACH92 & Ginger & Australia & $\mathrm{I} / 16$ & & (27) \\
\hline GMI1000 & Tomato & French Guyana & $\mathrm{I} / 18$ & & 1 \\
\hline CFBP2968 & Eggplant & Guadeloupe & $\mathrm{I} / 18$ & & 1 \\
\hline NCPPB3190 & Tomato & Malaysia & $\mathrm{I} / 18$ & & 1 \\
\hline CFBP2972 & Potato & Martinique & IIA/35 & & 1 \\
\hline CFBP2957 & Tomato & Martinique & IIA/36 & & 1 \\
\hline CFBP2958 & Tomato & Guadeloupe & IIA/39 & & 1 \\
\hline ICMP7963 & Potato & Kenya & IIA/7 & & (27) \\
\hline K60 & Tomato & USA & IIA/7 & & (27) \\
\hline IPO1609 & Potato & Netherlands & $\mathrm{IIB} / 1$ & YES & (27) \\
\hline JT516 & Potato & Reunion Is. & $\mathrm{IIB} / 1$ & YES & (27) \\
\hline UW551 & Geranium & Kenya & IIB/1 & YES & (38) \\
\hline CIP10 & Potato & Peru & $\mathrm{IIB} / 25$ & YES & (27) \\
\hline NCPPB3987 & Potato & Brazil & $\mathrm{IIB} / 28$ & YES & (27) \\
\hline MOLK2 & Banana & Philippines & $\mathrm{IIB} / 3$ & & (27) \\
\hline UW9 & Heliconia & Costa Rica & $\mathrm{IIB} / 3$ & & (27) \\
\hline CFBP1409 & Banana & Honduras & $\mathrm{IIB} / 3$ & & (27) \\
\hline CFBP1183 & Heliconia & Costa Rica & $\mathrm{IIB} / 3$ & & (27) \\
\hline UW70 & Banana & Colombia & $\mathrm{IIB} / 4$ & & (27) \\
\hline UW129 & Banana & Peru & $\mathrm{IIB} / 4$ & & (27) \\
\hline UW162 & Banana & Peru & $\mathrm{IIB} / 4$ & & (28) \\
\hline CFBP6784 & Anthurium & Martinique & $\mathrm{IIB} / 4$ & & (28) \\
\hline A3909 & Heliconia & Hawaii & IIA/6 & & (27) \\
\hline UW21 & Banana & Honduras & IIA/6 & & (28) \\
\hline CFBP734 & Potato & Madagascar & III/19 & & (28) \\
\hline JT525 & Geranium & Reunion Is. & III/19 & YES & (28) \\
\hline NCPPB332 & Potato & Zimbabwe & $\mathrm{III} / 22$ & & 1 \\
\hline CFBP3059 & Eggplant & Burkina Faso & $\mathrm{III} / 23$ & YES & 1 \\
\hline CIP358 & Potato & Cameroon (III) & $\mathrm{III} / 29$ & & 1 \\
\hline MAFF301558 & Potato & Japan & IV/8 & & 1 \\
\hline PSi7 & Tomato & Indonesia & $\mathrm{IV} / 10$ & & (27) \\
\hline
\end{tabular}

Table 2. Characteristics of agro-ecological zones (AEZ) in Cameroon

\begin{tabular}{|c|c|c|c|}
\hline $\begin{array}{l}\text { AEZ } \\
\text { (districts) }\end{array}$ & $\begin{array}{c}\text { Rainfall } \\
(\mathbf{m m})\end{array}$ & $\begin{array}{l}\text { Elevation } \\
{\text { (m.a.s.l. })^{\mathrm{a}}}\end{array}$ & $\begin{array}{l}\text { Mean annual } \\
\text { temp. (range) }\end{array}$ \\
\hline $\begin{array}{l}\text { I Sudano - sahelian zone } \\
\text { (Garoua) }\end{array}$ & $500-900$ & $250-500$ & $28^{\circ} \mathrm{C}(7.7)$ \\
\hline $\begin{array}{l}\text { II High Guinea savannah } \\
\text { (Ngaoundéré) }\end{array}$ & $1,500-1,800$ & $500-1,500$ & $23^{\circ} \mathrm{C}(6.4)$ \\
\hline $\begin{array}{l}\text { III Western highlands } \\
\text { (Bamougoum, Foumbot, Baham, Dschang, } \\
\text { Mbouda) }\end{array}$ & $1,800-2,400$ & $1,500-2,500$ & $21^{\circ} \mathrm{C}(2.2)$ \\
\hline $\begin{array}{l}\text { IV Humid forest (monomodal rainfall) } \\
\text { (Melong, Buea) }\end{array}$ & $2,000-11,000$ & $0-2,500$ & $26^{\circ} \mathrm{C}(2.8)$ \\
\hline $\begin{array}{l}\text { V Humid forest (bimodal rainfall) } \\
\text { (Yaoundé, Okola, Obala, Bafia, Akonolinga) }\end{array}$ & $1,500-2,000$ & $400-1,000$ & $25^{\circ} \mathrm{C}(2.4)$ \\
\hline
\end{tabular}

${ }^{a}$ Meters above sea level.

DNA typing. Phylotype multiplexpolymerase chain reaction (Pmx-PCR) of the 16S-23S ITS was used to determine the phylotype of each strain based on the methods and hierarchical classification scheme described previously (6). Briefly, Pmx-PCR includes the primers $759 / 760$ (23) as an internal marker to amplify the 280-bp "universal" $R$. solanacearumspecific reference band, plus a set of four phylotype-specific forward primers (Nmult:21:1F: 5'-CGTTGATGAGGCGCG CAATTT-3'; Nmult:21:2F: 5'-AAGTTA TGGACGGTGGAAGTC-3'; Nmult:22:InF: 5'-ATTGCCAAGACGAGAGAAGTA-3'; Nmult:23:AF: 5'-ATTACGAGAGCAATC GAAAGATT-3') with a unique and conserved reverse primer (Nmult:22:RR: 5'-TCGCTTGACCCTATAACGAGTA-3'). This Pmx-PCR produces the following phylotype-specific PCR products: a 144-bp amplicon from phylotype I strains; a 372bp amplicon from phylotype II strains; a 91-bp amplicon from phylotype III strains; and a 213-bp amplicon from phylotype IV strains. Strains that were classified as phylotype II were further tested using the PCR primer pair 630-F (5'-ATACAG AATTCGACCGGCACG-3') and 631-R (5'-AATCACATGCAATTCGCCTACG-3'), which specifically amplifies a 357-bp fragment from strains in phylotype II, sequevar 1, historically known as R3bv2 (8).

PCR amplification and DNA sequencing of the endoglucanase $(e g l)$ and DNA repair (mutS) genes. Strain genetic diversity and phylogeny were further characterized by comparative analysis of the partial nucleotide sequences of the endoglucanase (egl) and the DNA repair protein (mutS) genes. PCR amplifications of a 750-bp region of the egl gene were performed using the primer pair Endo-F (5'ATGCATGCCGCTGGTCGCCGC-3') and Endo-R (5'-GCGTTGCCCGGCACGAAC ACC- $\left.3^{\prime}\right)(6)$. The reaction mixture $(50 \mu \mathrm{l}$, total volume) contained $1 \times$ PCR buffer (supplied by the manufacturer), $1.5 \mathrm{mM}$ $\mathrm{MgCl}_{2}, 200 \mu \mathrm{M}$ of each dNTP, 4 pmol of each primer, a $2 \mu \mathrm{l}$ volume of a turbid bacterial suspension as template (about 5 $\mathrm{ng} / \mu \mathrm{l})$, and $1 \mathrm{U}$ of AmpliTaq Gold DNA Polymerase (Applied Biosystems, Foster City, CA). Reaction mixtures were heated to $96^{\circ} \mathrm{C}$ for $9 \mathrm{~min}$ and then cycled through 30 cycles of $1 \mathrm{~min}$ at $95^{\circ} \mathrm{C}, 40 \mathrm{~s}$ at $55^{\circ} \mathrm{C}, 2$ min at $72^{\circ} \mathrm{C}$, with a 10 min final extension at $72^{\circ} \mathrm{C}$, and a final hold at $12^{\circ} \mathrm{C}$. Amplification of the 758-bp fragment of the mutS gene was performed in a total volume of $25 \mu \mathrm{l}$ containing $1 \times$ PCR buffer (Promega, Charbonnières-les-Bains, France), $1.5 \mathrm{mM}$ $\mathrm{MgCl}_{2}, 0.2 \mathrm{mM}$ of each dNTP, $0.8 \mu \mathrm{M}$ DMSO, $1.25 \mathrm{U}$ of $\mathrm{Taq}$ Polymerase (Promega), 9 pmol of the primers mutSRsF.1570 (5'-ACAGCGCCTTGAGCCGGT ACA-3') and mutS-RsR.1926 (5'-GCT GATCACCGGCCCGAACAT- ${ }^{\prime}$ ), and $2 \mu \mathrm{l}$ of a turbid bacterial suspension as template (about $5 \mathrm{ng} / \mu \mathrm{l}$ ). Reaction mixtures were 
first heated to $96^{\circ} \mathrm{C}$ for $5 \mathrm{~min}$, and then cycled through 35 cycles of $1 \mathrm{~min}$ at $94^{\circ} \mathrm{C}$, $1 \mathrm{~min}$ at $66^{\circ} \mathrm{C}$, and $1.5 \mathrm{~min}$ at $72^{\circ} \mathrm{C}$, with a 5-min final extension at $72^{\circ} \mathrm{C}(27)$. All
PCR amplifications were performed using an MJ PTC100 thermocycler (MJ Research, Bio-Rad Laboratories, Inc., Hercules, CA). Samples $(5 \mu \mathrm{l})$ of PCR reaction
Table 3. Phylotype distribution of Ralstonia solanacearum strains collected in Cameroon within agroecological zones (AEZ) based upon DNA typing using phylotype multiplex-polymerase chain reaction (PCR) and the race 3/biovar 2 (R3bv2)-specific 630/631 PCR tests

\begin{tabular}{|c|c|c|c|c|c|}
\hline \multirow[b]{3}{*}{ AEZ } & \multicolumn{4}{|c|}{ No. of strains } & \multirow{3}{*}{$\begin{array}{l}\text { Total no. } \\
\text { of strains }\end{array}$} \\
\hline & \multirow[b]{2}{*}{ Phylotype I } & \multicolumn{2}{|c|}{ Phylotype II subcluster/sequevar } & \multirow[b]{2}{*}{ Phylotype III } & \\
\hline & & A/non-R3bv2 & B/1 (R3bv2) & & \\
\hline II & 0 & 1 & 0 & 0 & 1 \\
\hline III & 0 & 11 & 5 & 14 & 30 \\
\hline IV & 0 & 1 & 0 & 5 & 6 \\
\hline V & 50 & 22 & 0 & 1 & 73 \\
\hline $\begin{array}{c}\text { Total no. of } \\
\text { strains }(\%)\end{array}$ & $50(45.5)$ & $35(31.8)$ & $5(4.5)$ & $20(18.2)$ & 110 \\
\hline $\begin{array}{l}\text { Hosts of } \\
\text { isolation }\end{array}$ & $\begin{array}{c}\text { Tomato } \\
\text { Potato } \\
\text { Pepper } \\
\text { Huckleberry } \\
\text { Amaranth }\end{array}$ & $\begin{array}{c}\text { Tomato } \\
\text { Pepper } \\
\text { Huckleberry }\end{array}$ & $\begin{array}{l}\text { Tomato } \\
\text { Potato }\end{array}$ & $\begin{array}{c}\text { Tomato } \\
\text { Potato } \\
\text { Pepper } \\
\text { Huckleberry }\end{array}$ & \\
\hline
\end{tabular}

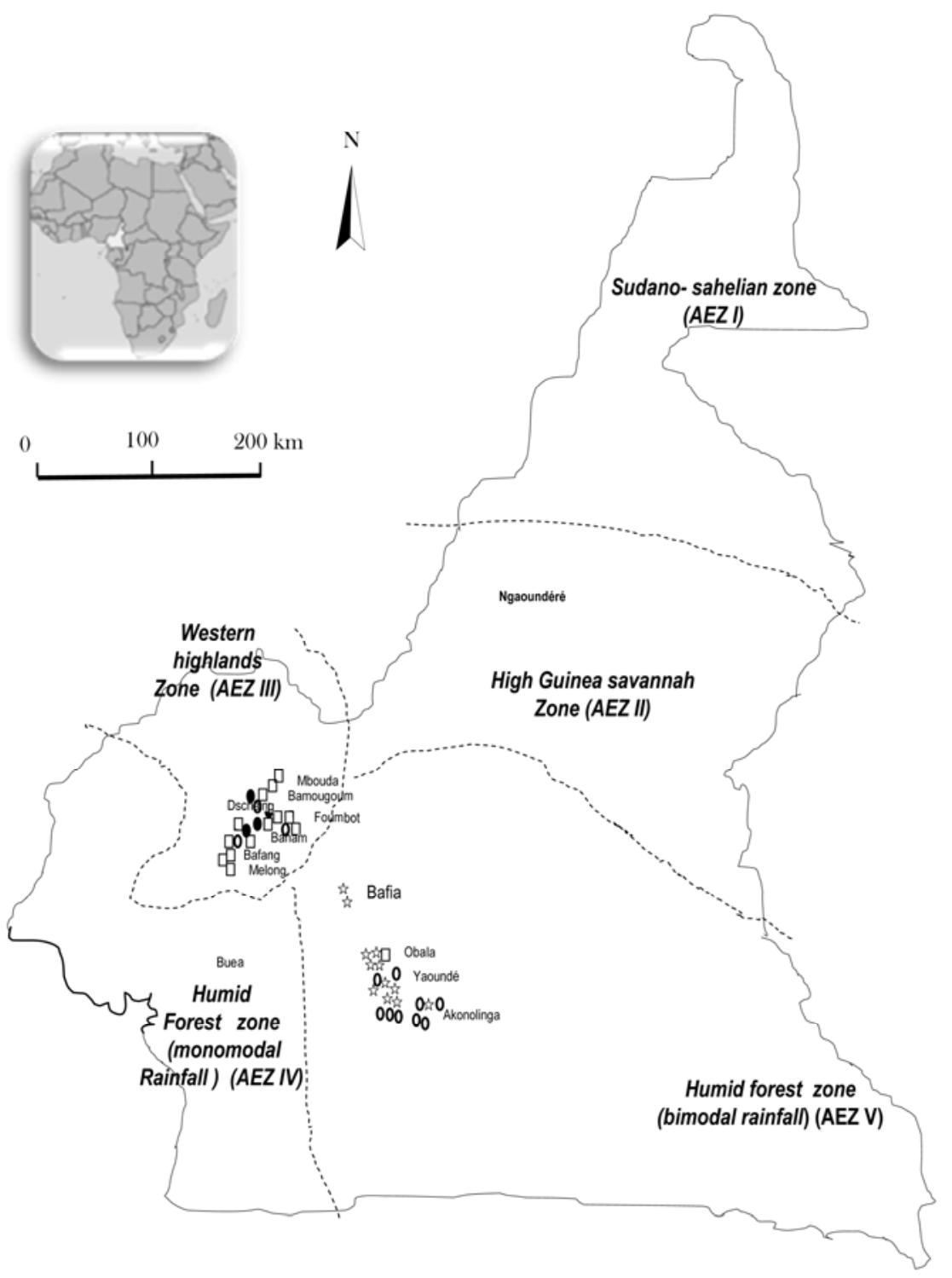

Fig. 1. Map of Cameroon showing the five agro-ecological zones and the locations where Ralstonia solanacearum strains of phylotype I (stars), IIA (open circles), IIB (closed circles), and III (open squares) were sampled. mixtures were resolved on a $2 \%$ Trisacetate-EDTA agarose electrophoresis gel, and PCR products were revealed by staining DNA in $0.5 \mu \mathrm{g} \cdot \mathrm{ml}^{-1}$ ethidium bromide. PCR products were sent to MWG-biotech (Ebersberg, Germany) for purification and sequencing of both strands. For both $e g l$ and $m u t S$ genes, PCR primers used to amplify partial sequence of these genes were also used as sequencing primers.

Sequence analysis and construction of phylogenetic trees. The partial sequences of the chromosomally located housekeeping gene mutS and the megaplasmidlocated virulence gene $e g l$ were analyzed using the ARB Software Environment (19) (http://www.arb-home.de/). Sequences were manually aligned using the ARB sequence editor. Evolutionary relationships between sequences were analyzed using the three major phylogenetic approaches offered by the ARB Software: (i) using the algorithm of Jukes and Cantor (16), phylogenetic trees were constructed from the genetic distance data by using the neighbor-joining (NJ) method (32) with 5,000 bootstrap resamplings of the data to test the tree topologies; (ii) maximum likelihood (ML) methods using the FastDNAml program; and (iii) the maximum parsimony (MP) methods using the Phylip DNAPARS package implemented by the ARB software. From the pool of $m u t S$ and $e g l$ sequences included in this study (77 and 76 sequences, respectively), representative reference strains were identified, and sequences from newly described strains were deposited into the GenBank database.

\section{RESULTS}

$R$ solanacearum strain collection. A total of $110 R$. solanacearum strains were recovered from wilted tomato, sweet and hot pepper, potato, huckleberry, amaranth, and sesame plants (Table 1). Bacterial wilt is widely distributed in Cameroon, but disease incidence and severity were highest in AEZ V (Yaoundé, lowlands) and AEZ III (Bafoussam, highlands), which are also the main vegetable cropping areas of Cameroon. The phylotyping results of the $110 R$. solanacearum strains by AEZ are reported in Table 3. From these 110 strains, a set of 44 representative strains collected in Cameroon was selected for phylogenetic analysis (Table 1), including strains from all phylotypes and most of the hosts. No $R$. solanacearum strains were obtained from AEZ I (Fig. 1).

PCR-based identification and characterization of $R$. solanacearum strains. Multiplex PCR analyses demonstrated that three of the four $R$. solanacearum phylotypes were present in Cameroon: the Asian phylotype I, the American phylotype II, and the African phylotype III (Table 4). Strains of phylotype I constituted the largest group (45.5\% of the 110 strains). Strains of phylotype II represented 35\% of the collection. Among these phylotype II 
strains, $5 \%$ were identified as sequevar 1 (R3bv2) because the characteristic R3bv2specific 304-bp band was amplified from their DNA using the 630/631 primer pair. Strains of African phylotype III represented only $18 \%$ of the 110 collected isolates.

Pathogenicity. All Cameroon strains tested $(n=7)$ were pathogenic on potato (Table 4). Plants developed symptoms approximately 5 days after inoculation, showing a typical leaf margin rolling-up and epinasty, followed by a generalized and characteristic wilt. All strains except the reference R3bv2 strain IPO1609 $(13,39)$ were pathogenic to tomato. Cameroon strains CMR15 and CMR43, as well as reference strains IPO1609, CIP10, and NCPPB3987, were classed as not pathogenic to pepper because no symptoms developed 4 weeks after inoculation.

Phylogenetic analysis. Partial $e g l$ and mutS gene sequences were generated from a set of representative strains from Cameroon $(n=44)$ and compared with those from $R$. solanacearum reference strains covering the known genetic diversity within the four phylotypes $(6,27)$. Trees constructed with maximum likelihood, parsimony, and distance NJ phylogenetic approaches were totally congruent; therefore, we present only NJ phylogenetic trees with bootstrap values (Figs. 2 and 3 ). Trees constructed with $e g l$ and $m u t S$ sets of sequences were in general agreement with one difference in topology: phylotype III was most closely related to phylotype II in the egl-derived tree, while it was more closely related to phylotype I in the mutS tree. Apart from this different branching order, trees constructed using the two different sequences showed similar branching patterns clearly partitioning the four phylotypes as previously described (6). The reference strains from phylotypes I, II, III, and IV clustered separately with high bootstrap values.

The 44 representative strains collected in Cameroon were classified into phylo- types according to Pmx-PCR results (Table 1). Phylotype I strains were isolated from various hosts including tomato, Solanum nigrum (CMR96 and CMR134), and Amaranthus spp. (CMR111) produced in the hot and humid lowland AEZ V. These strains were closely related according to both $e g l$ and $m u t S$ sequence analyses.

Phylotype II strain DNA sequences resolved into two main branches: subclusters A and B (7). Within subcluster A, all strains isolated from tomato and huckleberry had $e g l$ sequences differing by less than $1 \%$ from the $e g l$ sequence of sequevar 35 reference strain CFBP2972 (P. Prior, INRA-CIRAD, Réunion, unpublished data). They were thus assigned phylotype IIA sequevar 35 (IIA/35). Within subcluster $\mathrm{B}$, all strains were indistinguishable from reference sequevar 1 strains IPO1609 (The Netherlands) and JT516 (Reunion Island) (27). These phylotype IIB/1 strains were all isolated in the cool highlands of AEZ III from potato plants with brown rot symptoms (CMR24, CMR44) and from wilting tomato plants (CMR18, CMR34, CMR35).

Phylotype III strains from Cameroon fell, for most of these, in a subgroup near the reference strain CIP358, previously typed as phylotype III/29 (P. Prior, INRACIRAD, Réunion, unpublished data). The strain CMR66 was more closely related to the phylotype III/23 reference strain CFBP3059 from Burkina Faso (6). No strains collected in Cameroon in this study belonged to phylotype IV, the Indonesian cluster of $R$. solanacearum.

Geographic distribution of phylotypes in Cameroon. The distribution of phylotypes within the agro-ecological zones visited in this study reflected some epidemiological traits of $R$. solanacearum strains (particularly regarding virulence/temperature relationships) (Table 3). $R$. solanacearum was mainly isolated in the humid lowland AEZ V and in the highland AEZ III. Phylotype III strains were found in AEZ III, IV, and V, with a majority collected in AEZ III, which is a major potato and tomato cropping area. Phylotype II strains were found in AEZ II, III, and IV; however, phylotype IIB strains were more prevalent in the highlands of West Cameroon (AEZ III), whereas phylotype IIA strains, isolated from various hosts, were distributed among all AEZs visited. All phylotype I strains were collected in the lowland AEZ V (see Figure 1 and Table 2 for AEZ characteristics).

\section{DISCUSSION}

Bacterial wilt, caused by $R$. solanacearum, was observed in the major vegetable cropping areas of highland and lowland regions surveyed in Cameroon. In this country, farmers from all the regions visited were familiar with bacterial wilt, called "Djom-djom" disease in the Obala area (AEZ V), literally translated as "sleep-sleep" referring to the sudden wilt of tomatoes; "Sudden-death" in Baham (AEZ III); "Water-disease" in Foumbot (AEZ III) in the highlands of West Cameroon; and "Direct-attack" by tomato growers in Buea (AEZ IV) on the slopes of Mount Cameroon. One hundred and ten strains of $R$. solanacearum were collected from the major cash and/or subsistence crops, and 44 representative strains were positioned in the global phylogenetic scheme of the $R$. solanacearum species complex (6), along with 33 reference strains. These analyses revealed a high genetic diversity among the pathogen strains collected in this country. Phylotype assignment by Pmx-PCR was perfectly congruent with phylogenetic positioning based on sequences of $e g l$ and mutS genes.

Cameroon strains of $R$. solanacearum belonged to three of the four previously described phylotypes (6): I, II, III. The presence in Africa of these three groups was previously known (5), but our study is the first to describe the distribution of the three phylotypes in a single Central Afri-

Table 4. Pathogenicity of selected Ralstonia solanacearum strains on potato, tomato, and pepper

\begin{tabular}{|c|c|c|c|c|c|c|}
\hline \multirow[b]{2}{*}{ Strain $^{a}$} & \multirow[b]{2}{*}{ Host } & \multirow[b]{2}{*}{ Origin $^{b}$} & \multirow{2}{*}{$\begin{array}{l}\text { Phylotype and } \\
\text { subclusterc }^{c}\end{array}$} & \multicolumn{3}{|c|}{ Pathogenicity on } \\
\hline & & & & Potato & Tomato & Pepper \\
\hline CMR134 & Huckleberry & Bafia (V) & I & + & + & + \\
\hline CMR39 & Tomato & Dschang (III) & IIA & + & + & + \\
\hline CMR120 & Tomato & Yaoundé (V) & IIA & + & + & + \\
\hline CMR34 & Tomato & Baham (III) & IIB & + & + & + \\
\hline JT516 & Potato & Reunion Is. & IIB & + & + & + \\
\hline UW551 & Geranium & Kenya & IIB & + & + & + \\
\hline IPO1609 & Potato & Netherlands & IIB & + & - & - \\
\hline NCPPB3987 & Potato & Brazil & IIB & + & + & - \\
\hline CIP10 & Potato & Peru & IIB & + & + & - \\
\hline CMR43 & Potato & Dschang (III) & III & + & + & - \\
\hline CMR15 & Tomato & Obala (V) & III & + & + & - \\
\hline CMR78 & Pepper & Melong (IV) & III & + & + & + \\
\hline JT525 & Geranium & Reunion Is. & III & + & + & + \\
\hline CFBP3059 & Eggplant & Burkina Faso & III & + & + & + \\
\hline Control (water) & & & & - & - & - \\
\hline
\end{tabular}

a Strains from Cameroon (CMR) and references.

${ }^{\mathrm{b}}$ District (agro-ecological zone) in Cameroon or country of origin.

${ }^{c}$ Phylotypes and subclusters were determined by $e g l$ and $m u t S$ sequence analyses. 
can country. Phylotype I strains of $R$. solanacearum represented almost half of the collected strains and were over-represented in AEZ V of Yaounde, a warm and humid lowland region, especially in the rainy season of March (Table 4). This result confirms previous reports on phylotype I (ex-biovar 3) strains originating from Southern Africa $(24,25)$. As expected from this group, they were found in several host species including tomato, potato, pepper, huckleberry, and amaranth. Phylotype I strains may thus be considered the major bacterial wilt constraint for vegetable crops in the lowland bimodal humid forest region of Cameroon (AEZ V; Yaoundé, Akonolinga, Obala, Bafia).

In contrast, phylotype III and phylotype IIB (R3bv2) strains were preferentially isolated from AEZ III, a highland cropping area with a temperate climate (Baham,
Bafoussam, Bamougoum, Dschang, Foumbot). Strains from phylotype IIA were found in both AEZ III and AEZ V. A further survey including a systematic collection sampling method may help to refine and validate these geographic distribution patterns.

Among the phylotype II strains of $R$. solanacearum, we noted differing host range and geographical distributions for IIA and IIB strains. Phylotype IIA strains were isolated from, and prevalent on, tomato and huckleberry crops in all regions sampled, with a majority of the strains originating from the lowland areas. Phylotype IIB/1 (R3bv2) strains were only isolated from potato and tomato in the highland AEZ III, the major potato cropping region. These strains, which are considered to be near-clonal, are hypothesized to have adapted (coevolved) with potato (10). This study confirms that strains in phylotype IIB/1 have a host range that is not limited to potato under natural African highland and tropical conditions. This finding is of major concern for tomato growers in Cameroon, as well as in other African countries where phylotype II/1 strains (R3bv2) have been reported, including Nigeria (35), Uganda, Rwanda, and Tanzania (5), Ethiopia (18), and South Africa (5,9). Indeed, some phylotype IIB/1 strains are highly virulent on the most commonly used wiltresistant tomato lines (2).

We show here that phylotype III strains of Cameroon have the same host range (potato and tomato) and the same cool highland environment (AEZ III) as phylotype IIB/1 strains, and caused the same brown rot-like syndrome on potato. Although indistinguishable on the basis of symptom development, disease severity in

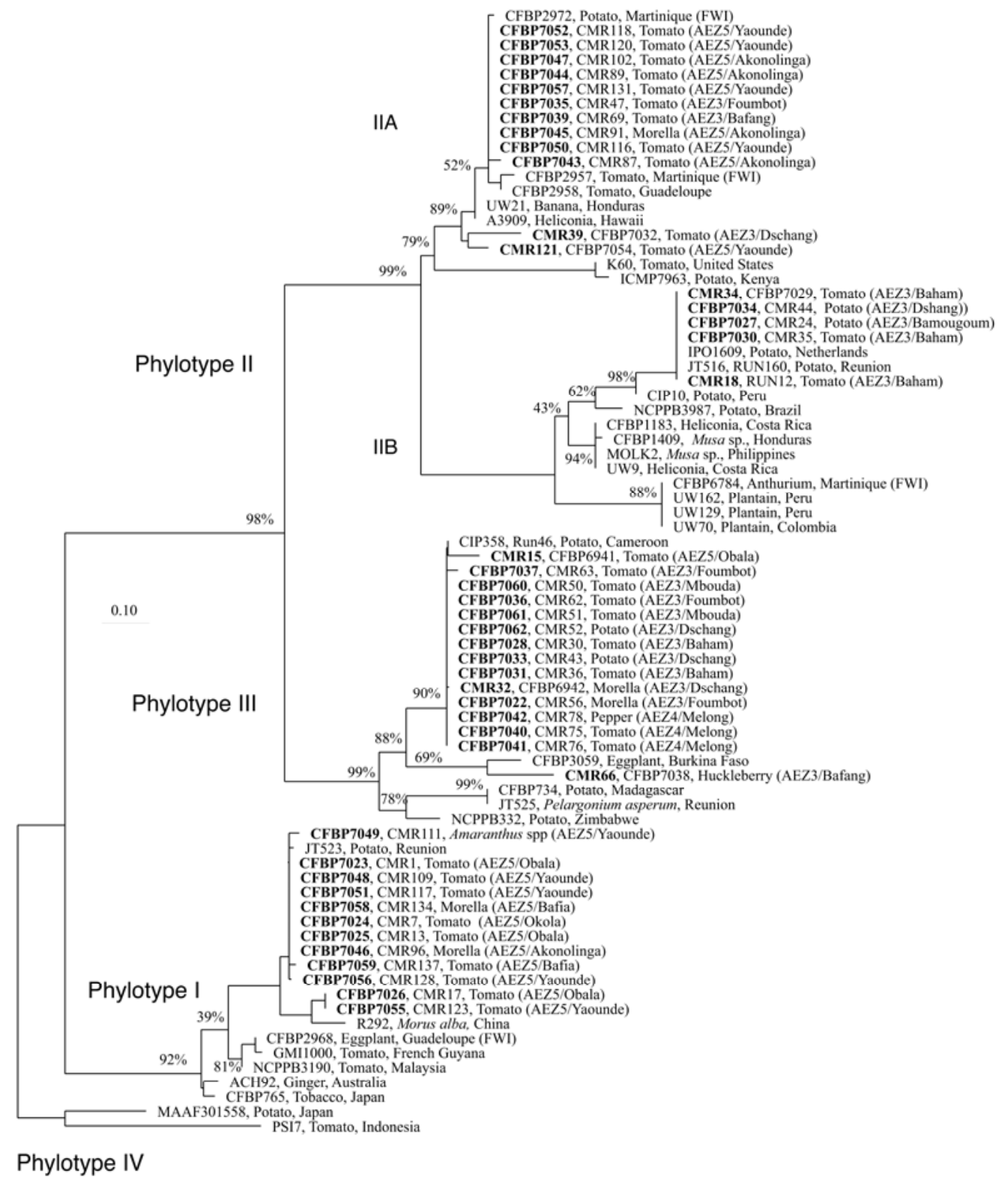

Fig. 2. Phylogenetic neighbor-joining tree based on the partial endoglucanase (egl) gene sequences of strains from Cameroon and Ralstonia solanacearum species complex reference strains. The number at each node is the bootstrap value (5,000 resamplings), and significant bootstrap values less than $100 \%$ are indicated at each node. Scale bar represents 1 nucleotide substitution per 100 nucleotides. 
potato, and prevalence in cool potato growing areas, $R$. solanacearum strains that cause wilt in potato in the highland areas of Cameroon should be referred to as (i) the African brown rot group, composed of phylotype III strains, and (ii) the Andean brown rot group, composed of phylowere introduced through imported latently infected potato tubers. The presence of these two phylogenetically distinct but epidemiologically congruent pathogen groups in the West African highlands must be taken into account in the development of control strategies, including diagnostic tools and especially regional disease resistance breeding programs.

Phylogenetic analysis of $R$. solanacearum strains collected in Cameroon and comparisons with reference strains from neighboring countries revealed that the recently described phylotype III (6), formerly described as the "African biovar 1" strains $(24,25)$, encompasses broad varitype IIB/1 (R3bv2) strains that most likely

ability. Three subgroups with strong bootstrap support were observed, distinguishing (i) the southern Africa and Indian Ocean strains (III/19 and II/21), containing the reference strain NCPPB332 (from Zimbabwe), and phylotype III/19 reference strains CFBP734 (Madagascar) and JT525 (Reunion Island), (ii) the Central Africa strains, mostly represented in Cameroon (III/29), and (iii) a subgroup still poorly investigated, containing the strain CMR66, and the phylotype III/23 reference strain CFBP3059 from Burkina Faso (6). We thus tentatively propose further subdivision of phylotype III into three clusters, awaiting further data from additional African strains for confirmation. Additional panAfrican studies in southern, central, and northern Africa should reveal the genetic variability that remains to be described within phylotype III.

As a follow-up to this study, a typical lowland phylotype III strain, CMR15 (CFBP6941), is being completely se-

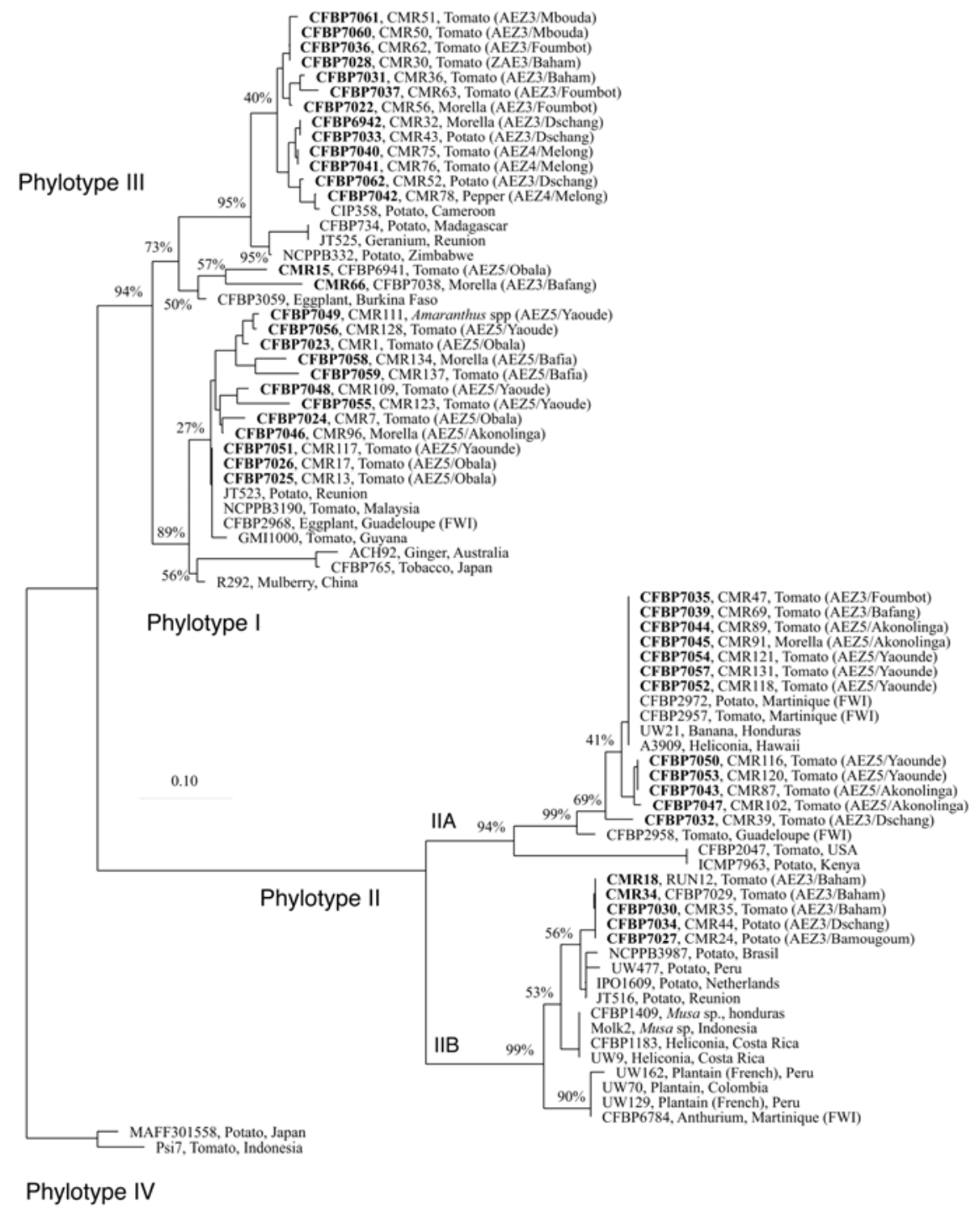

Fig. 3. Phylogenetic neighbor-joining tree based on partial sequences of the DNA repair mutS gene from strains from Cameroon and Ralstonia solanacearum species complex reference strains. The number at each node is the bootstrap value (5,000 resamplings), and significant bootstrap values less than $100 \%$ are indicated at each node. Scale bar represents 1 nucleotide substitution per 100 nucleotides. quenced to investigate the conserved and specific gene repertoires of these hitherto poorly described strains within the $R$. solanacearum species complex.

This study provides the first comprehensive information on genetically diverse strains of $R$. solanacearum in the Central African country of Cameroon. A recent survey in Ethiopia (18), although based on biovar classification, suggests that the diversity we found in Cameroon is not unique in Africa. The relationships between the wide genetic diversity and strain virulence phenotypes demands further investigation. Understanding the biological implications of such broad genetic diversity is critically important for the development of locally adapted strategies for bacterial wilt resistance breeding in Cameroon and other African countries that share similar agro-ecological environments.

\section{ACKNOWLEDGMENTS}

This research was supported by grants from the French Ministry of Foreign Affairs (French Embassy in Yaoundé) and from the Delegation for International Scientific Exchanges, CIRAD. We thank M. Fegan, A. Guidot, and L. Gagnevin for critically reviewing the manuscript.

\section{LITERATURE CITED}

1. Busolo-Bulafu, C. M. 1998. Resistance to bacterial wilt in Uganda. Pages 306-308 in: Bacterial wilt disease: Molecular and ecological aspects. P. Prior, C. Allen, and J. G. Elphinstone, eds. INRA Editions, Paris.

2. Carmeille, A., Prior, P., Kodja, H., Chiroleu, F., Luisetti, J., and Besse, P. 2006. Evaluation of resistance to race 3, biovar 2 of Ralstonia solanacearum in tomato germplasm. J. Phytopathol. 154(7-8):398-402.

3. Cook, D., Barlow, E., and Sequeira, L. 1989. Genetic diversity of Pseudomonas solanacearum: Detection of restriction fragment length polymorphisms with DNA probes that specify virulence and the hypersensitive response. Mol. Plant-Microbe Interact. 2:113-121.

4. Coutinho, T., Roux, J., Riedel, K., Terblanche, J., and Wingfield, M. 2000. First report of bacterial wilt caused by Ralstonia solanacearum on eucalypts in South Africa. - Erstnachweis einer durch Ralstonia solanacearum verursachten Bakterienwelke an Eukalyptus in Sndafrika. For. Pathol. (Germany) 30(4).

5. Elphinstone, J. G. 2005. The current bacterial wilt situation: A global overview. Pages 9-28 in: Bacterial Wilt Disease and the Ralstonia solanacearum Species Complex. C. Allen, P. Prior, and A. C. Hayward, eds. American Phytopathological Society, Saint Paul, MN.

6. Fegan, M., and Prior, P. 2005. How complex is the "Ralstonia solanacearum species complex". Pages 449-462 in: Bacterial Wilt Disease and the Ralstonia solanacearum Species Complex. C. Allen, P. Prior, and A. C. Hayward, eds. American Phytopathological Society, Saint Paul, MN.

7. Fegan, M., and Prior, P. 2006. Diverse members of the Ralstonia solanacearum species complex cause bacterial wilts of banana. Australas. Plant Pathol. 35:93-101.

8. Fegan, M., Taghavi, M., Sly, L. I., and Hayward, A. C. 1998. Phylogeny, diversity and molecular diagnostics of Ralstonia solanacearum. Pages 19-33 in: Bacterial Wilt Disease Molecular and Ecological Aspects. P. Prior, C. Allen, and J. Elphinstone, eds. Springer, INRA Editions, Berlin. 
9. Fouche, W. J., Poussier, S., Trigalet, D. D., Berger, D., and Coutinho, T. 2006. Molecular identification of some African strains of Ralstonia solanacearum from eucalypt [Eucalyptus] and potato [Solanum tuberosum]. J. Gen. Plant Pathol. (Japan) 72(6):369-373

10. Gillings, M. R., and Fahy, P. 1994. Genomic fingerprinting: Towards a unified view of the Pseudomonas solanacearum species complex. Pages 95-112 in: Bacterial Wilt: The Disease and Its Causative Agent, Pseudomonas solanacearum. A. C. Hayward and G. L. Hartman, eds. CAB International, Wallingford, UK

11. Gockowski, J., Mbazo'o, J., Mbah, G., and Fouda Moulende, T. 2003. African traditional leafy vegetables and the urban and peri-urban poor. Food Policy 28:221-235.

12. Grimault, V., and Prior, P. 1994. Grafting tomato cultivars resistant or susceptible to bacterial wilt: Analysis of resistance mechanisms. J. Phytopathol. 141(3):330-334.

13. Guidot, A., Prior, P., Schoenfeld, J., Carrere, S., Genin, S., and Boucher, C. 2007. Genomic structure and phylogeny of the plant pathogen Ralstonia solancearum inferred from gene distribution analysis. J. Bacteriol. 189(2):377387.

14. Hanson, P. M., Wang, J.-F., Lucardo, O., Hanudin, S. Y., Hartman, G. L., Lin, Y.-C., and Chen, J.-T. 1996. Variable reactions of tomato lines to bacterial wilt evaluated at several locations in South-East Asia. HortScience 31:143146.

15. Ji, P., Momol, M. T., Olson, S. M., Pradhanang, P. M., and Jones, J. B. 2005. Evaluation of thymol as biofumigant for control of bacterial wilt of tomato under field conditions. Plant Dis. 89:497-500.

16. Jukes, T. H., and Cantor, C. R. 1969. Evolution of protein molecules. Pages 21-132 in: Mammalian Protein Metabolism. H. N. Munro, ed. Academic Press, New York.

17. Kelman, A. 1954. The relationship of pathogenicity in Pseudomonas solanacearum to colony appearance on tetrazolium medium. Phytopathology 44:693-695.

18. Lemessa, F., and Zeller, W. 2007. Isolation and characterisation of Ralstonia solanacearum strains from Solanaceae crops in Ethiopia. J. Basic Microbiol. 47(1):40-49.

19. Ludwig, W., Strunk, O., Westram, R., Richetr, L., Meier, H., Yadhukumar, Buchner, A., Lai, T., Steppi, S., Jobb, G., Förster, W., Brettske, I., Gerber, S., Ginhart, A. W., Gross, O., Grumann, S., Hermann, S., Jost, R., König, A., Liss, T., Lüssman, R., May, M., Nonhoff, B., Reichel, B., Strehlow, R., Stamatakis, A., Stuckmann, N., Vilbig, A., Lenke, M., Ludwig, T., Bode, A., and Schleifer, K. H. 2004. ARB: A software environment for sequence data. Nucleic Acids Res. 32(4):1363-1371.

20. Madden, L. V., and Wheelis, M. 2003. The threat of plant pathogens as weapons against U.S. crops. Annu. Rev. Phytopathol. 41:155176.

21. Michel, V. V., and Mew, T. W. 1998. Effect of a soil amendment on survival of Ralstonia so- anacearum in different soils. Phytopathology 88:300-305.

22. Michel, V. V., Wang, J.-F., Midmore, D. J., and Hartman, G. L. 1997. Effects of intercropping and soil amendment with urea and calcium oxide on the incidence of bacterial wilt of tomato and survival of soil-borne Pseudomonas solanacearum in Taiwan. Plant Pathol. 46:600610.

23. Opina, N., Tavner, F., Hollway, G., Wang, J.-F., Li, T.-H., Maghirang, R., Fegan, M., Hayward, A. C., Krishnapillai, V., Hong, W. F., Holloway, B. W., and Timmis, J. 1997. A novel method for development of species and strainspecific DNA probes and PCR primers for identifying Burkholderia solanacearum (formerly Pseudomonas solanacearum). Asia $\mathrm{Pa}-$ cific J. Mol. Biol. Biotechnol. 5:19-30.

24. Poussier, S., Trigalet-Demery, D., Vandewalle, P., Goffiner, B., Luisetti, J., and Trigalet, A. 2000. Genetic diversity of Ralstonia solanacearum as assessed by PCR-RFLP of the hrp region, AFLP and 16S rRNA sequence analysis, and identification of an African subdivision. Microbiology 146:1679-1692.

25. Poussier, S., Vandewalle, P., and Luisetti, J. 1999. Genetic diversity of African and worldwide strains of Ralstonia solanacearum as determined by PCR-restriction fragment length polymorphism analysis of the hrp gene region. Appl. Environ. Microbiol. 65(5):2184-2194.

26. Pradhanang, P. M., Ji, P., Momol, M. T., Olson, S. M., Mayfield, J. L., and Jones, J. B. 2005. Application of acibenzolar- $S$-methyl enhances host resistance in tomato against Ralstonia solanacearum. Plant Dis. 89:989-993.

27. Prior, P., and Fegan, M. 2005. Recent development in the phylogeny and classification of Ralstonia solanacearum. Pages 127-136 in: Proc. 1st Int. Sympos. Tomato Dis. T. Momol and J. B. Jones, eds. ISHS-Acta Hortic.

28. Prior, P., and Fegan, M. 2005. Recent developments in the phylogeny and classification of Ralstonia solanacearum. Acta Hortic. 695:127-136.

29. Prior, P., Grimault, V., and Schmit, J. 1994. Resistance to bacterial wilt (Pseudomonas solanacearum) in tomato: Present status and prospects. Pages 209-224 in: Bacterial wilt: The disease and its causative agent, Pseudomonas solanacearum. A. Hayward and G. L. Hartman, eds. CAB International, Wallingford, UK.

30. Ran, L. X., Liu, C. Y., Wu, G. J., Loon, L. C. v., and Bakker, P. A. H. M. 2005. Suppression of bacterial wilt in Eucalyptus urophylla by fluorescent Pseudomonas spp. in China. Biol. Control 32(1):111-120.

31. Robertson, A. E. 1998. Factors affecting the population of Ralstonia solanacearum in a naturally infested field planted to tobacco. Pages 369-373 in: Bacterial Wilt Disease: Molecular and Ecological Aspects. P. Prior, C. Allen, and J. G. Elphinstone, eds. INRA Editions, Paris.

32. Saitou, N., and Nei, M. 1987. The neighborjoining method: A new method for recon- structing phylogenetic trees. Mol. Biol. Evol. 4:406-425.

33. Sanchez Perez, A., Mejia, L., Fegan, M., and Allen, C. 2008. Diversity and distribution of Ralstonia solanacearum strains in Guatemala and rare occurence of tomato fruit infection Plant Pathol. 57:1-12.

34. Schönfeld, J., Gelsomino, A., Overbeek, L. v., Gorissen, A., Smalla, K., and Elsas, J. v. 2003. Effects of compost addition and simulated solarisation on the fate of Ralstonia solanacearum biovar 2 and indigenous bacteria in soil. FEMS Microbiol. Ecol. 43:63-74.

35. Smith, J. J., Offord, L. C., Holderness, M., and Saddler, G. S. 1995. Genetic diversity of Burkholderia solanacearum (synonym Pseudomonas solanacearum) race 3 in Kenya. Appl. Environ. Microbiol. 61:4263-4268.

36. Smith, J. J., Offord, L. C., Kitaba, G. N. Murimi, Z. K., Trigalet, A., and Saddler, G. S 1998. The development of biological control agents against Ralstonia solanacearum race 3 in Kenya. Pages 306-308 in: Bacterial Wilt Disease: Molecular and Ecological Aspects. P. Prior, C. Allen, and J. Elphinstone, eds. INRA Editions, Paris.

37. Swanpoel, A. E., and Young, B. W. 1988 Characteristics of South African strains of Pseudomonas solanacearum. Plant Dis. 72:403-405

38. Swanson, J. K., Yao, J., Tans-Kersten, J., and Allen, C. 2005. Behavior of Ralstonia solanacearum race 3 biovar 2 during latent and active infection of geranium. Phytopathology 95:136143.

39. van Elsas, J. D., Kastelein, P., van Bekkum, P., van der Wolf, J. M., de Vries, P. M., and van Overbeek, L. S. 2000. Survival of Ralstonia solanacearum biovar 2 , the causative agent of potato brown rot, in field and microcosm soils in temperate climates. Phytopathology 90:1358-1366.

40. Wang, J.-F., Chen, N.-C., and Li, H.-M. 1998. Resistance sources of bacterial wilt in eggplant (Solanum melongena). Pages 284-289 in: Bacterial Wilt Disease: Molecular and Ecological Aspects. P. Prior, C. Allen, and J. Elphinstone, eds. Springer, INRA editions, Berlin, Paris.

41. Wang, J.-F., Hanson, P., and Barnes, J. A. 1998. Worldwide evaluation of an international set of resistant sources to bacterial wilt in tomato. Pages 269-275 in: Bacterial Wilt Disease: Molecular and Ecological Aspects. P Prior, C. Allen, and J. G. Elphinstone, eds. Springer-Verlag, Berlin

42. Wydra, K., and Dannon, E. 2006. Silicon as inducer of resistance in tomato against Ralstonia solanacearum. Bull. OILB/SROP 29:91-

43. Yoon, J. Y., Green, S. K., Tschanz, A. T., Tsou, S. C. S., and Chang, L. C. 1989. Pepper improvement for the tropics: Problems and the AVRDC approach. Pages 86-98 in: Tomato and pepper production in the tropics- Proc. Int Sympos. Integrated Manag. Practices. S. K. Green, T. D. Griggs, and B. T. McLean, eds. AVRDC, Tainan, Taiwan. 